\title{
SUCCESS MEASUREMENT OF BUSINESS PROCESSES
}

\author{
Ivica KANIŠKI, Ivan VINCEK
}

\begin{abstract}
A business process is an activity or set of activities that accomplish a specific goal of an organization. In almost every organization there are three important pillars that keep the whole organization together - people, processes and technology. All three are linked and if one of them does not work well, others can easily collapse. Success Measurement is a complex activity that includes at least four disciplines: economics, IT, management and accounting, implying the process of quantifying the effectiveness and effectiveness of an action. Success Measurement is a dynamic system that supports the decision-making process by collecting and analyzing information.
\end{abstract}

Keywords: analysis of business processes; business processes; measuring success; program tools

\section{INTRODUCTION}

The effectiveness and overall business results of any business organization largely depend directly on the way in which business processes are managed, i.e. the business relations and all business activities necessary for the realization of the set organizational goals.

Market environment and heavy competition in business direct many organizations in terms of the necessity of the existence of business marketing in the market of business consumption and it being conditioned by quality management of business processes.

It is necessary to implement radical and significant changes in a company's business conduct that will result with lower expenses and shorter production cycle, accompanied by the quality of goods or services. Those changes are directed at the reforming, restructuring and innovation of business processes by the use and support of IT.

\section{BUSINESS PROCESSES}

Business processes can be described as a sequence of logically connected activities that use resources of a company and that have an end goal of satisfying the customers' needs for goods or services of a certain quality and price, in an adequate time frame and simultaneous realization of certain values. [1]

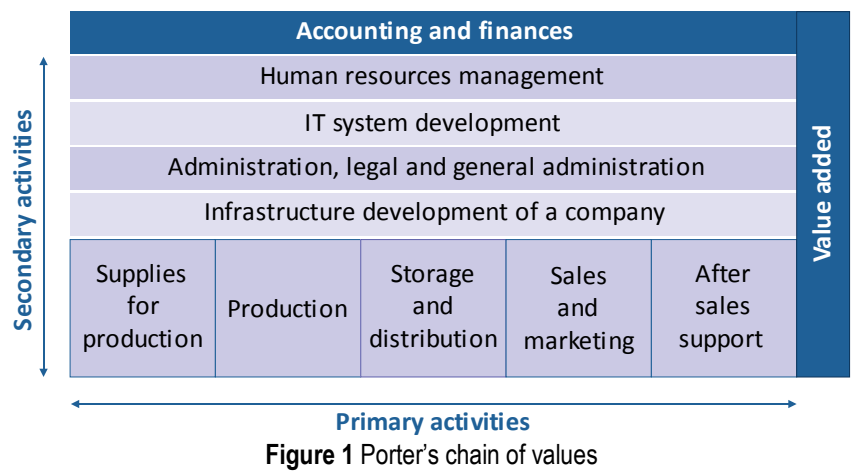

We can measure the efficiency of a process carried out in time and the expenses required to turn the input values of a process into an output result.

Processes are elements of each company, but they are rarely described or analyzed. In organizations that are not production oriented, processes are not clearly defined and it is difficult to describe them precisely.

\subsection{Analysis of Business Processes}

The business process analysis is especially useful for attaining goals related to consumers, and for efficiency and profitability. Moreover, the whole business process analysis can be helpful in checking whether control systems are in place to lower the risks, i.e. risk exposure.

The business process analysis is primarily performed in order to determine:

- activities that do not add value,

- redundant activities or tasks (repeated in different parts of organization or repeated because of errors)

- sequential activities and tasks that can be conducted at the same time, i.e. that can overlap,

- activities performed only based on experience (which can be very dangerous because the business practice is not documented),

- imbalance between directional processes and enabling processes

- inadequate use of technology,

- insufficient training, education and staff

knowledge/experience,

- modes of giving feedback,

- liaisons between missing processes,

- unnecessary reports,

- inadequate rules and procedures. [2]

The business process analysis often uses: the comparison of documentation procedures, business process mapping, whole process observation, root cause analysis, critical path analysis, matrix analysis, correlation matrix, Pareto analysis, force-field analysis, process restriction 
analysis, cultural factor analysis, analysis of added value, scenario analysis, etc. [2]

Regardless of the choice of its conduct, the analysis of a specific business process mainly begins with the analysis of current activities. It needs to be stressed that it is more difficult to carry out the analysis of an existing process than to create a new process, because the existing process does not necessarily need to be logical or make sense, while the proposed business process is generally logical.

The analysis of an existing process attempts to determine its quality, its bottleneck, weak areas and areas critical for improvement. Quality analysis includes the consideration of all activities within a given process and the identification of the modes of measuring all other processes that contribute to the success of a certain process. [2]

\subsection{Business Performance Perception Framework}

The defined matrix, the framework of how we perceive a company's success, can be seen on three levels and from three different perspectives: goals and success measurement, design and its implementation and the management's practice. With the help of a matrix, nine different elements were identified that need to be taken into consideration when improving business processes.

Besides the process level, both the organizational and individual level need to be emphasized and attention must be paid to the fact that the approach focused exclusively on the process level or the perspective of measuring the success and business processes management is not whole. Performance indicators of all three levels need to be taken into account as a whole.

Table 1 Framework for the business performance perception

\begin{tabular}{|c|c|c|c|}
\hline & $\begin{array}{l}\text { Objectives and } \\
\text { performance } \\
\text { measurement }\end{array}$ & $\begin{array}{l}\text { Design and } \\
\text { usage }\end{array}$ & $\begin{array}{l}\text { Management } \\
\text { practice }\end{array}$ \\
\hline $\begin{array}{l}\text { Organizational } \\
\text { level }\end{array}$ & $\begin{array}{l}\text { Organizational } \\
\text { objectives and } \\
\text { the measuring of } \\
\text { organizational } \\
\text { success }\end{array}$ & $\begin{array}{c}\text { Organizational } \\
\text { design and its } \\
\text { use }\end{array}$ & $\begin{array}{c}\text { Managing an } \\
\text { organization }\end{array}$ \\
\hline Processual level & $\begin{array}{c}\text { Process } \\
\text { objectives and } \\
\text { the measuring of } \\
\text { the success of a } \\
\text { process }\end{array}$ & $\begin{array}{l}\text { Process design } \\
\text { and its } \\
\text { application }\end{array}$ & $\begin{array}{c}\text { Process } \\
\text { management }\end{array}$ \\
\hline Individual level & $\begin{array}{c}\text { Individual } \\
\text { objectives and } \\
\text { the measuring of } \\
\text { individual } \\
\text { success }\end{array}$ & $\begin{array}{l}\text { Design of } \\
\text { activities and its } \\
\text { application }\end{array}$ & $\begin{array}{l}\text { Managing } \\
\text { activities }\end{array}$ \\
\hline
\end{tabular}

\subsection{Business Controlling}

Often, in times of economic crisis, a need appears for making an extra effort to solve certain difficulties in a company's business caused by external or internal factors. It is because of such character of the art of controlling that its main function is aimed at achieving the highest possible business efficiency. [6]
Because of market globalization, throughout the last few decades, there was a significant turn in the way companies conduct their business. Consumers' needs are getting more and more demanding regarding the price, but also quality.

Markets saturated with unlimited amounts of goods and services offered come as a turning point in the way of managing and designing business strategies for companies.

One of the most significant problems of contemporary companies' expansion and development is a decrease in the transparency of the business conduct as a whole and less coherence of individual organizational units. It is more and more difficult to manage companies that have grown in such a way.

Controlling is a function of leadership without which it is difficult to imagine a contemporary company. It solves the ever increasing problems of coordination and integration.

One of the reasons for the occurrence of controlling could be the separation of the ownership function from the function of management, which leads to difficulties in communication and leadership. One of the reasons why controlling appeared as such could be the emergence of the need for a faster business decision-making. It is this multidisciplinary feature of controlling that implies the need for a more precise definition of it. The primary role of controlling is the merging of different parts of a company into a whole unit with the goal of creating a comprehensive perspective of its overall business conduct. It links partial organizational functions into a single unit to maximize the effectiveness and efficiency of a company.

The outset for the execution of controlling is based on the company's accounting, spreading out onto all other organizational elements with the goal of creating a compact unit.

Although the concept of controlling changed over time, it can be said that controlling came into existence based on the accounting concept. [2]

\subsection{Role of Controlling in a Company}

Although controlling relates to business operations of a company as a whole, a large portion of it consists of a plan and analysis. Due to controlling, management should be informed of everything that takes place with the goal of better quality decision-making. In large companies, situations often occur where each department works independently and partially also independently sets certain goals, which can lead to incoherently set goals. The role of controlling in such a company is connecting those departments in order to create unique goals and plans. [2]

One of the most important goals of controlling is planning business operations. Planning helps to anticipate certain outcomes in business operations which helps decrease possible risks to the lowest level possible. Planning operations significantly increases the chances of attaining goals. Although there are different levels of planning, the ones that stand out as the most significant ones would be: strategic, tactics and operational planning. 
By means of planning, different organizational units meet through partial operational plans of the whole company. The main task of controlling is to align partial plans by taking into account all important information gathered within and outside the company. In order to successfully align partial plans, controlling has to find the causes of mutual misalignment. Besides the mentioned, controlling also has the role to check the reality of proposed plans.

Nowadays, a good quality informational system represents a base for the quality functioning of controlling. Considering the fact that controlling has the role to pick the most crucial information for decision-making, a good quality informational system can represent an insurmountable link in quality decision-making and reporting. One can say that accounting is the center of informational systems within a company. The goal of controlling is to pick the accounting information that are crucial for quality decision-making.

The role of controlling in a company can be the formulating of new or the restructuring of the already existing organizational structure for an easier and more complete flow of important data and information to the staff in charge with it. The organization of a company has to be set up in a way that facilitates the realization of specified value systems to the maximum.

\section{MEASURING THE SUCCESS OF BUSINESS OPERATIONS}

The fundamental goal of a company's existence and business operations is business success. An important factor that is related to business success and that needs to be pointed out is the idea of measuring the performance and the success of business operations. To measure the success of business operations means to have a clearly defined scale of values and a tool that will be used to measure success.

Efficacy is stated as a principle and an aggregate index of the correlations between the output and input. When mentioned in the context of companies, efficacy stands for the success of a company related to its use of the resources available, regardless of how resources have been allocated. Efficiency, performance or productivity stands for achieving the basic goals of a company. The idea of efficiency as a measure includes the evaluation of whether the company manages to unify its many goals and to what extent. It is related to the idea of strategic company management. [3]

\subsection{Financial Indicator Analysis}

In the business operations' analysis, there are many methods, techniques and the variant quality of information that are at the disposal of various interest groups. For that reason, it can be concluded that financial analysis is all but unified. It is a fact that the object of interest for financial analysis is the company itself, therefore it is important to discern whether the analysis is carried out externally or internally, which will depend on who is in charge with it and in whose interest it is for the analysis to be done. It could be owners, investors, creditors or all other interest groups.

\begin{tabular}{|c|c|c|}
\hline \multicolumn{2}{|c|}{ Table 2 Illustration of the earning power indicator formation } \\
\hline Inidicator & $\begin{array}{c}\text { Numerator } \\
\text { Denominator }\end{array}$ \\
\hline Return on sale (ROS) & $\begin{array}{c}\text { Income } \\
\text { (net or gross) }\end{array}$ & Revenue (turnover) \\
\hline $\begin{array}{c}\text { Income } \\
\text { Return on investment } \\
\text { (ROI, ROA) }\end{array}$ & \begin{tabular}{c} 
Total funds \\
\hline Return on equity (ROE)
\end{tabular} & Net income \\
\hline
\end{tabular}

When talking about external analysis, carried out by the financial analysts performing the role of the future or current owners or investors of a company, it is most often carried out exactly by the financial indicators, that have their base calculation in the externally (publicly) available data, which is, of course, limited. On the contrary, internal analysis is conducted by the company's manager, who has all the existing data at his disposal.

The use of financial indicators can be systematically divided into:

- comparison of the company's performance throughout a particular period of time,

- comparison of various companies,

- comparison of different industries. [3]

The indicators that are calculated by using the data of financial reports can be divided into a few categories, normally into the following groups:

- earning power indicators,

- activity indicators,

- liquidity indicators,

- indicators of financing and company indebtedness.

\subsubsection{Earning Power Ratio}

The indicators of the earning power of a company have always been and still are an important objective of the business operations' success analysis as part of the financial report analysis.

Taking this into consideration, it can be concluded that only the companies that have a big earning power can win new business domains and markets, create new work posts, and at the same time assure their owners that the rate of return will be at least at the level of a certain risk (in the form of dividends, bonus rate pay or in the form of the stocks or share value increase).

However, earning power is one of those company features that is very difficult to specify and measure.

The return on sale, return on investment and return on equity are the indicators we get by using the financial report data. They are the indicators of the company's income, deficit and balance. [3]

\subsubsection{Activity Ratio}

Activity ratio measures how successful a company was in managing the assets it has. The ratios from this group are also called turnover ratios and they can be calculated as a relation between the revenue and any kind of funds. To do 
that, turnover data from the revenue report is used, as well as the funds' status reported in the balance sheet or the averages of certain forms of assets.

The most calculated ones are the turnover ratio of the funds invested, turnover ratio of the long-term assets, current assets or the turnover ratio of one of the entries of short-term assets i.e. claims, inventory or cash.

$$
\begin{aligned}
& \text { Asset turnover ratio }=\frac{\text { total revenue }}{\text { total assets }} \\
& \text { Inventory turnover ratio }=\frac{\text { total revenue }}{\text { inventory }} \\
& \text { Receivable turnover ratio }=\frac{\text { total revenue }}{\text { receivables }}
\end{aligned}
$$

Ratios of the duration of the receivable turnover ratio, inventory turnover ratio, asset turnover ratio and the duration of the accounts payable are very important because they indicate the speed at which cash flow takes place in a company. It is both the liquidity and the profitability of company business operations that depend on the average speed of cash flow. The cash flow cycle deals with all the components of a company, but it is especially focused on four entries in the balance and those are: cash, cash equivalents, inventory, receivables and the accounts payable. Money and money equivalents are linked to forms such as inventory and receivables and that is why, from the cash flow perspective, it is important for those entries to be as small as possible, i.e. for the time of their link to be as short as possible. [3]

\subsubsection{Liquidity Ratio}

Liquidity stands for the ability of a certain kind of asset to turn into money. Another meaning of the term is the ability of a company to settle all the received short-term liabilities.

Liquidity ratios are a part of the so-called ratios of the horizontal financial structure because they put into relation certain parts (short-term assets) with other parts (short-term liabilities) and with the goal of defining the company's ability to keep its liquidity. There are a few indicators of liquidity, the two most common are the so-called current ratio and quick ratio. [3]

The current ratio of liquidity is calculated:

Current ratio $=\frac{\text { short term assets }}{\text { current liabilities }}$

Current ratio is the proportion of short-term and current assets and the short-term or current liabilities.

Quick ratio is calculated:

Quick ratio $=\frac{\text { cash }+ \text { marketable securities }+ \text { accounts receivable }}{\text { current liabilities }}$

\subsubsection{Ratio of the Financing and Using of Financial Leverage}

Financing ratios show the importance of the owner structure of financing and interest charge, as well as other fixed remunerations that arise as a consequence of using external sources of financing. The most common ratios of this group are:

- Debt-to-asset ratio,

- Debt-to-equity ratio,

- Coverage ratio. [3]

Debt-to-asset ratio $=\frac{\text { total debt }}{\text { total assets }}$

The debt-to-asset ratio shows what level of risk the company's creditors are subject to considering the financial structure of a source, and it shows what the fixed interest charge that burdens a company's business operations is.

Debt-to-equity ratio $=\frac{\text { total debt }}{\text { equity }}$

The debt-to-equity ratio can also be calculated as a relation between the long-term liabilities and the majority of the ownership equity because such a ratio is convenient for the optimization of the company's financial structure.

Debt-to-equity ratio $=\frac{\text { long-term liabilities }}{\text { equity }}$

\subsection{Measuring Success by Relative Ratios of Success}

When measuring the global (total) results of a company, we have to discern different influences so that economics could adequately interpret that the effects of each one of the necessary element influences by its effect on the end result. At the starting point of the contemporary idea business success, there is the idea of the economic principle or the principle of the least assets, which expresses tendency to:

- Accomplish the maximum effect (outputs, income, returns, profits) by using the resources at the disposal (sources, inputs, expenses, assets, investments or the socalled sacrifice);

- Accomplish the desired effects through a minimal investment of resources. [3]

Measuring success through manufacturing, costeffectiveness and profitability of labor gives the necessary data about different results. This information will be especially needed if it is known that other companies with identical global results accomplish higher wages or dividends, or the faster rate of development (because they are capable of extracting funds for the development of an investment). Not only is the goal to attain the data of the causes of the results' variance, but also to measure the need which has to be taken to make them relatively bigger.

\subsubsection{Labor PRODUCTIVITY}

The influence of human labor on the productivity of a company is called labor productivity or just productivity. Namely, labor productivity is the relationship between the total value of the output and labor hours invested into creating those outputs. 
The simplest formula or the outset for calculating productivity is:

\section{Labor productivity $=$ total output/labor hours}

The numerator of the abovementioned formula can also be:

- product quantity (pieces, tons, meters etc.),

- sales transactions (expressed in amount or money)

- transfer of goods, people and information,

- number of overnight stays in tourism, etc. [3]

\subsubsection{Cost-Effectiveness}

When dealing with cost-effectiveness, it is necessary to analyze individual segments of business operations or each individual input needed for getting the desired outputs for a company to come into market with.

Taking cost-effectiveness as a comprehensive expression of efficiency, it needs to be linked to the idea of economizing, which could be best defined as the rational management or rational, economic treatment of all elements that have an impact on achieving results and realizing income. Consequently, one can say that a comprehensive expression of efficiency can be explained as a relation between the total income and total expenses that occurred with the goal of making income. The relation is:

$$
E=\frac{\sum \text { income }}{\sum \text { expenses }}[3]
$$

The quotient of this ratio shows how many kuna of income have been realized compared to each kuna spent. That is a significant indicator and it says a lot about the success of a business operation. The quotient expressed by an absolute number is enough of an indicator whether the business is economical or not.

If the quotient is:

- higher than 1 , the business is economical,

- lower than 1 , the business is uneconomical,

- equal to 1 , the business is on the verge of being economical - there is no financial result. [3]

\subsubsection{Return on Assets}

The realization of income, i.e. profit, is the motive that inspires every entrepreneur to realize his or her business ideas and profit by initiating business processes. As the conditions in which business operations of companies take place may vary, the results will be different, too. By determining the ratio of the return on assets (income) and investments or expenses needed for the profit to come into realization, we measure the profitability or rentability. Profitability, as a part of an analysis, can be seen as a principle or indicator of success by the help of relative indexes of success. [3]

As a principle, it shows the rationality of a business process by attempting to achieve the maximum business profit with the assets invested (principal funds, capital), i.e. by realizing the profit with the minimum investments, assets or one's own capital. As an index, profitability reflects the realistic state of the ratio between the profit and the assets invested. Operationally, it shows how many money units of a business profit are gained per unit of assets invested or how many units of assets need to be invested to achieve one unit of business profit. [3]

The general pattern of measuring rentability is the ratio between the profit (income) and capital:

Asset profitability $=\frac{\text { income }}{\text { assets }} \times 100$

When we put total expenditure of a company (i.e. expenses) into the denominator, we get a return on assets.

Return on assets $=\frac{\text { business income }}{\text { business expenses }} \times 100$

Accordingly, it is only the assets' profitability that can be considered the real indicator of profitability as it indicates how many units of business results are realized per each monetary unit of invested assets. [3]

\subsection{Measuring Success in Terms of Value Based Management (VBM)}

A lack of the coherence of goals in different interest groups in a company should be solved by applying value based management (VBM).

To achieve a viable value creation, a manager's success should be measured by means of criteria that can be directly linked to creating a value for owners. In a certain sense, VBM represents a mixture of different economic disciplines and subjects. For instance, the goal of increasing value for the company's owners was taken from financing, together with the discounted cash flow technique. The principle of value creation as a result of investing in the company's activities in which the company has comparative advantages before the potential and existing competition was taken from the field of business strategies. It was from accounting that the adjusted basic structure of financial reports was taken.

VBM is a combination of principles, convictions and processes that make it possible for a company to be successful in fighting the competition from the outside and the institutional imperatives within a company. From a general point of view, VBM can be defined as an integrated system of management and control which measures and supports the creation of values. [3]

Important features of VBM:

- Management - VBM represents a system of controlling and managing, i.e. a certain set of tools used in unifying resources and tasks with the purpose of achieving certain goals,

- Concept - basic values of the concept are definitely and permanently conducted through all levels of an organization,

- Maximizing the company owner's values - basic purpose of VBM is to create as much as possible of a 
net value by allocating the company's resources to the most valuable investments, which includes predicting and focusing on the future results of a business. [3]

VBM is an integrating process of improving the operational and strategic decision-making of a company as a whole. In a company that has accepted the concept of managing focused on value, the managing processes such as planning and the estimation of success offer the decision makers certain data and encouragement that help them conduct the measures that lead to the basic goal of business, the growth of value.

The procedure of setting the goals of VBM is based on the next principles:

- goals need to include the financial and non-financial aspects and need to be based on the quality components of a particular business activity,

- goals have to be adjusted to the level of managing that they are being set for,

- mutual time inter-relatedness of goals is necessary, too, i.e. for the long-term goals to be the continuation of the long-term ones. [3]

The biggest error that can arise when assessing the success of management and consequently awarding the managers is connecting the managers' success to the accounting results, instead of evaluating the success related to the realization of a certain strategy or the specific indicators of a certain activity.

The following principles apply for the system of business success evaluation:

- rating the success of a specific business unit - each unit in a company is assessed based on its own success indicators,

- relating success assessment to the short-term and longterm goals of a specific business unit,

- combining the financial and operational criteria based on value factors,

- introduction of indicators that operate as systems of an early forewarning of a possible crisis. [3]

VBM can be seen as a continuous process which begins with strategic planning so as to achieve the comparative advantages that will generate the growth of economic profits and the shareholders' yield. The economic features of an industrial environment in which a company makes business determine the form of financial reports of a company which are reflected through the analysis of the traditional criteria of success.

\section{PROGRAM TOOLS FOR BUSINESS PROCESSES}

The goal of all program tools for modeling and of the analysis of business processes is to document and analyze the existing business processes and propose improvement based on that analysis.

Tools for modeling and the analysis of business processes are program solutions that managers, IT experts, analysts and end users apply for creating the models of business processes in an organization, for storing the data of those models and their analysis. From the functionality point of view, those tools enable the documentation and analysis of the existing situation and the documentation of the proposal of the improvement and analysis of the expected effects of the proposed changes. [1]

Program tools for managing business processes differ in capabilities, reliability and the adjustment with the IT standards. They also differ in prices and that is why making a decision on which one to choose is very difficult.

Producers of the tools for managing business processes implement different strategies so as to achieve the biggest possible success on the market. Some producers adjust their program solutions to the specifications of certain businesses, and some develop universal program solutions, applicable to all companies. [1]

\section{CONCLUSION}

It is most important to point out that the success of making business has to be attuned to the business strategy of a company. Business indicators are the inevitable tools of examining and exploring a company's business efficacy. The right choice is possible only in case when the mission, vision and goal projects get clearly defined by the management.

Because of the global competition on the market, companies can achieve the competitive advantage only by offering cheaper and better quality products and services, for which efficient and innovative business processes are needed. Performing business processes is in the focus of the attention of the management and their strategy. For that reason, business processes become the core of a company's functioning, because it is all about processes before products or services.

Companies that want to be successful have to embrace the principles of business orientation. Process orientation is not a synonym for the process organizational structure. It determines understanding the course of business and it is only the first step in the process-oriented organizational structure.

For a successful conduct of projects, it is very important to apply the appropriate program tools. The decision of the choice of the optimal program tool depends on the quality and the options of a tool, but also on the goals of a project. Even the best tools can turn out to be very bad if we try to apply them to the environment that does not have enough knowledge to use them or understand them.

The more different methods there are built into a tool, the better; more options are offered, but at the same time they are more complex and expensive.

\section{REFERENCES}

[1] Bosilj Vukšić, V. \& Kovačić, A. (2004). Upravljanje poslovnim procesima. Sinergija nakladništvo, Zagreb.

[2] Bosilj Vukšić, V., Hernaus, T., \& Kovačić, A. (2008). Upravljanje poslovnim procesima: Organizacijski $i$ informacijski pristu. Školska knjiga, Zagreb. 
[3] Dvorski, S. \& Kovšca, V. (2011). Ekonomija za poduzetnike. Tiva tiskara, Varaždin.

[4] Marić, G. (2006). Upravljanje poslovnim procesima. Školska knjiga, Zagreb.

[5] Žugaj, M. \& Cingula, M. (1992). Temelji organizacije. Foing, Varaždin.

[6] Nidžara Osmanagić, B. (2007). Kontroling - Abeceda poslovnog uspjeha. Školska knjiga, Zagreb.

[7] http://agririsk.agr.hr/Upravapdf/Poslovni_pokazatelji. pdf (Accessed on 15.08.2017)

[8] http://www.agr.unizg.hr/cro/nastava/oduli/doc/87437 pokazatelji_uspjesnosti.pdf (Accessed on 15.08.2017)

Authors' contacts:

Ivica Kaniški, mag.oec.

Ante Starčevića 38, G. Kneginec

42204 Turčin, Croatia

099/372-0774

ivica.kaniski@gmail.com

Ivan Vincek, mag.oec.

Jurketinec 60, 42243 Maruševec, Croatia

091/501-8171

ivanvincek92@gmail.com 